\title{
Perilaku Berisiko dan Keluhan Subjektif Memori (KSM) pada Kelompok Umur 25 Tahun ke Atas di Kota Bogor Tengah
}

\author{
Risk Behavior and Subjective Cognitive Complaint on 25 Years and Above in Central Bogor City
}

\author{
Julianty Pradono*
}

Puslitbang Upaya Kesehatan Masyarakat, Badan Litbangkes, Kementerian Kesehatan RI, JL. Percetakan Negara No. 29 Jakarta Pusat, Indonesia

*Korespondensi Penulis: jpradono@yahoo.com

Submitted: 25-06-2018, Revised: 25-07-2018, Accepted: 30-07-2018

DOI: http://dx.doi.org/10.22435/mpk.v28i2.122

\begin{abstract}
Abstrak
Prevalensi keluhan subjektif memori (KSM) semakin meningkat selama 10 tahun terakhir. Keluhan subjektif memori mencerminkan tanda awal penyakit neurodegeneratif yang akan berkembang menjadi demensia. Tujuan penelitian ini untuk mendapatkan incidence rate KSM dan mendapatkan prediktor terjadinya KSM di Kota Bogor. Sampel penelitian merupakan subsampel kohor prospektif sebanyak 3.260 responden dengan rerata umur 47,6 $\pm 9,7$ tahun dan bebas KSM di awal analisis. Data dikumpulkan dengan metode wawancara, pengukuran, dan pemeriksaan yang dilakukan setiap 2 tahun. Faktor risiko meliputi karakteristik, status kesehatan, dan perilaku berisiko. Analisis data dengan uji chi-square dan logistik regresi. Hasil penelitian menyatakan insiden KSM sebesar 216 orang per 1.000 penduduk per 2 tahun. Setelah menyesuaikan faktor umur, prediktor KSM adalah kurang aktivitas fisik (OR 1,9 kali, 95\% $\mathrm{Cl}: 1,6-2,3)$, obesitas sentral (OR 1,2 kali, 95\% Cl:1,0-1,5), asupan natrium $\geq 2000 \mathrm{mg}$ per hari (OR 0,6 kali, $95 \% \mathrm{Cl}: 0,5-0,7)$, gangguan mental (OR 1,9 kali, 95\% Cl:1,6-2,3) dan migrain (OR 1,6 kali, 95\% Cl:1,3-1,9) terhadap insidens KSM. Disimpulkan bahwa insiden KSM sebesar 216 orang per 1.000 penduduk per 2 tahun. Prediktor KSM adalah kurang aktivitas fisik, obesitas sentral, asupan natrium $\geq 2000 \mathrm{mg}$ per hari, gangguan mental dan migrain. Disarankan bahwa intervensi spesifik seperti olahraga teratur, pertahankan berat badan ideal, tidak obese abdominal, tidak stres dan perhatikan intake garam, terutama pada usia lanjut, asupan garam tidak terlalu rendah.
\end{abstract}

Kata kunci: KSM (keluhan subjektif memori), perilaku berisiko

\begin{abstract}
The prevalence of subjective cognitive complaints (SCC) is increasing over the last 10 years. Subjective cognitive complaints reflect early signs of neurodegenerative disease that will develop into dementia. The objective of the study was to obtain the incidence rate of SCC and to get predictors of SCC in Bogor City. The sample was prospective cohort sample as much as 3260 respondents with mean age $47.6 \pm 9.7$ years and no SCC at the beginning of analysis. Data were collected by interview, measurement and laboratory examination every 2 years. The risk factors include characteristics, health status and risk behavior. Data was analyzed using chi-square test and regression logistic. The incidence of SCC was 216 persons per 1,000 population per 2 years. After adjusting for age, the SCC predictors were less physical activity (OR 1.9 time; $95 \%$ Cl: 1.6-2.3), central obesity (OR 1.2; 95\% Cl: 1.0-1, 5), intake of sodium $\geq 2000 \mathrm{mg}$ per day (OR 0.6; 95\% Cl: 0,5-0,7), mental disorder (OR 1.9; 95\% Cl: 1.6-2.3) and migraine (OR 1.6 times, 95\% Cl: 1.3-1.9) on the incidence of SCC. It is concluded that the incidence rate of SCC is 216 people per 1,000 population per 2 years. Predictors of SCC are less physical activity, central obesity, intake of sodium $\geq 2000$ mg per day, mental disorders and migraine. It is suggested that specific interventions such as increasing physical activity regularly, maintaining ideal body weight with no risk of abdominal obese, avoiding stress and controlling salt intake, especially in elderly respondents do not take too low intake.
\end{abstract}

Keywords: KSM (Cognitive subjective complaint), risky behavior 


\section{PENDAHULUAN}

Keluhan subjektif memori $(\mathrm{KSM} / \mathrm{SCC}=$ Subjective Cognitive Complaints) telah menarik perhatian selama beberapa dekade, karena fenomena ini mencerminkan tanda-tanda awal penyakit neurodegeneratif. ${ }^{1}$ Keluhan subjektif memori sering dikaitkan dengan penurunan kognitif objektif pada beberapa tahun ke depan dan terjadi konversi dari kognisi normal menjadi gangguan kognitif ringan atau demensia. ${ }^{2}$ Gangguan kognitif ringan merupakan sindrom yang ditandai dengan penurunan kognitif yang lebih luas dari yang diperkirakan untuk umur dan tingkat pendidikan seseorang, tanpa mengganggu aktivitas sehari-hari. Prevalensi dalam studi epidemiologi berbasis populasi berkisar antara 3-19\% terjadi pada kelompok umur lebih dari 65 tahun. Beberapa penelitian menunjukkan, gangguan kognitif ringan dapat stabil dan normal dari waktu ke waktu, tetapi lebih dari setengah akan berkembang menjadi demensia dalam kurun waktu 5 tahun. Dengan demikian kerusakan kognitif ringan dapat dianggap sebagai salah satu faktor risiko terjadinya demensia, dan dapat dimanfaatkan sebagai upaya pencegahan dalam mengendalikan penyakit tersebut. ${ }^{3}$ Demensia sering diasosiasi kelompok usia lanjut. Memang demensia banyak terjadi pada orang lanjut usia, tetapi ini bukan merupakan bagian normal dari suatu proses penuaan. ${ }^{3}$

Di dunia, setiap tahun ada hampir 10 juta kasus baru, diperkirakan pada populasi kelompok umum 60 tahun ke atas dengan demensia antara 5-8 per 100 orang. Jumlah penderita demensia diproyeksikan mencapai 82 juta pada tahun 2030 dan 152 juta pada tahun 2050. Sebagian besar jumlah penderita demensia tinggal di negara berpenghasilan rendah dan menengah. ${ }^{4} \mathrm{Hal}$ ini akan meningkatkan disabilitas dan merupakan beban negara.

Badan Pusat Statistik mencatat jumlah penduduk yang memiliki salah satu kriteria demensia, yaitu mengalami kesulitan mengingat dan konsentrasi sebanyak 4,07 juta jiwa pada kelompok umur 60 tahun ke atas, dengan jumlah terbanyak pada kelompok umur 75 tahun ke atas. ${ }^{5}$ Kurangnya kesadaran dan pemahaman tentang demensia, seringkali mengakibatkan stigmatisasi dan hambatan dalam melakukan diagnosis dan perawatan. Artikel ini menyajikan besaran masalah KSM di Kota Bogor Tengah dan menyajikan faktor risiko yang mempengaruhi gangguan kognisi subjektif tersebut.

\section{METODE}

Penelitian ini merupakan analisis lanjut dari sub bagian data "Studi Kohor Faktor Risiko Penyakit Tidak Menular (FRPTM)" yang dilaksanakan oleh Pusat Penelitian Upaya Kesehatan Masyarakat, Badan Penelitian dan Pengembangan Kesehatan, Kementerian Kesehatan RI sejak tahun 2011-2012. Studi kohor yang diikuti dengan pengamatan setiap dua tahunan yaitu pada tahun 2013-2014, tahun 2015-2016, dan tahun 2017-2018. Penilaian KSM baru ditambahkan pada kuesioner tahun 2014, sehingga data yang dikumpulkan yaitu data tahun 2014-2015 sebagai data dasar dan tahun 2016-2017 sebagai hasil pengamatan setelah 2 tahun. Besar sampel yang bisa ikut dalam analisis dengan dependen variabel KSM dan mempunyai kelengkapan data independen di setiap follow up, sebanyak 3.260 responden, sehingga analisis data dilakukan pada data tersebut. Instrumen yang digunakan berupa pertanyaan: apakah anda dianggap pelupa oleh orang lain (keluarga, teman, dll). Sebagai definisi operasional dalam analisis ini, KSM terjadi apabila responden menjawab "ya" atas pertanyaan tersebut. Desain penelitian kohort prospektif. Populasi penelitian adalah semua anggota rumah tangga yang berumur 2565 tahun di Kota Bogor Tengah. Sampel adalah semua anggota rumah tangga yang berumur 25-65 tahun dengan kriteria inklusi yaitu penduduk tetap yang dibuktikan dengan kartu identitas diri/ Kartu Tanda Penduduk (KTP) di wilayah penelitian, dapat mandiri, bersedia mengikuti pengamatan sesuai kriteria studi. Pengumpulan data dengan metode wawancara, pengukuran, dan pemeriksaan laboratorium darah.

Data yang dikumpulkan meliputi sosiodemografi (umur, jenis kelamin, status kawin, pendidikan, pekerjaan, status ekonomi), perilaku yaitu kebiasaan merokok yang dihitung berdasarkan indeks Brinkman, aktivitas fisik. Faktor risiko penyakit tidak menular yaitu obesitas sentral, indeks massa tubuh, tekanan darah, kadar gula darah (gula darah puasa, dan kadar gula darah 2 jam setelah pembebanan), profil lemak, dan konsumsi makanan.

Kelompok umur dibagi menjadi 2 kelompok yaitu 25-59 tahun dan 60 tahun atau lebih. Pembagian berdasarkan kriteria lansia di Indonesia. ${ }^{6}$ Pendidikan berdasarkan ijazah pendidikan terakhir yang dimiliki, dalam analisis dibagi menjadi tiga kategori, yaitu "rendah" bila tidak pernah sekolah; "sedang" apabila responden 
tamat sekolah dasar (SD) sampai dengan tamat sekolah lanjutan tingkat pertama (SLTP), dan "tinggi" bila tamat sekolah menengah atas (SMA) sampai dengan perguruan tinggi. Kebiasaan merokok dengan perhitungan indeks Brinkman yaitu merokok ringan jika pernah merokok 1 sampai 599 batang seumur hidup, sedangkan perokok berat bila merokok 600 batang atau lebih seumur hidup. Aktivitas fisik dikumpulkan berdasarkan wawancara kebiasaan aktivitas yang dilakukan sehari-hari dengan penggunakan Global Physical Activity Quesionnair (GPAQ) dengan memperhitungkan jenis dan lamanya aktivitas (hari per minggu dan lama aktivitas dalam jam, menit perhari). Aktivitas berat mempunyai bobot 8 kali, aktivitas sedang mempunyai bobot 4 kali, dan aktivitas ringan mempunyai bobot 2 kali. Responden dikategorikan kurang aktivitas apabila hasil perhitungan total aktivitas kurang dari 600 MET (metabolic equivalent) dalam satu minggu. ${ }^{7,8}$

Pengukuran lingkar perut menggunakan pita ukur. Lingkar perut diukur pada titik antara titik batas tepi tulang rusuk paling bawah dan titik ujung lengkung tulang pangkal paha dalam posisi berdiri tegak dan bernapas dengan normal. ${ }^{9}$ Kategori obesitas sentral, pada laki-laki dengan lingkar perut $>90 \mathrm{~cm}$ atau perempuan dengan lingkar perut $>80 \mathrm{~cm}^{10}$

Profil lipid meliputi pemeriksaan total kolesterol, high density lipoprotein, low-density lipoprotein, dan trigliserida. Pengkategorian profil lipid menurut National Cholesterol Education Program tahun 2002. Dalam analisis kadar total kolesterol dikategorikan menjadi dua, yaitu: normal $(<240 \mathrm{mg} / \mathrm{dl})$ dan tinggi $(\geq 240 \mathrm{mg} / \mathrm{dl})$, kadar kolesterol LDL terbagi menjadi normal $(<150 \mathrm{mg} / \mathrm{dl})$ dan tinggi $(\geq 150 \mathrm{mg} / \mathrm{dl})$. Kadar kolesterol HDL dikategorikan dua, yaitu: normal $(\geq 40 \mathrm{mg} / \mathrm{dl}$ ) dan rendah $(<40 \mathrm{mg} / \mathrm{dl})$. Selanjutnya kadar trigliserida dikategorikan menjadi dua juga, terdiri dari: normal $(<200 \mathrm{mg} / \mathrm{dl})$ dan tinggi $(\geq 200$ $\mathrm{mg} / \mathrm{dl}){ }^{11}$

Hipertensi didiagnosis berdasarkan hasil pengukuran tekanan darah dan riwayat minum obat antihipertensi, dengan batasan hipertensi apabila tekanan darah sistolik $\geq 140 \mathrm{mmHg}$ dan atau tekanan diastolik $\geq 90 \mathrm{mmHg} .^{12}$ Kriteria obesitas mengikuti kriteria WHO untuk populasi Asia Pasifik dengan nilai patokan indeks massa tubuh (IMT) pada $25 \mathrm{~kg} / \mathrm{m}^{2}$ sebagai cut-off risiko. ${ }^{13}$ Kriteria gula darah berdasarkan rekomendasi American Diabetes Association, kadar glukosa darah puasa (GDP) $\leq 99$ gr\% dan $\geq 100$ gr\%, dan kadar glukosa darah pasca 2 jam pembebanan glukosa (GDPP) $<140 \mathrm{mg} / \mathrm{dl}$ dan $\geq 140$ gr\%. ${ }^{14}$

Gangguan mental dikumpulkan dengan cara wawancara, menggunakan instrument Self Reported Quesionaire (SRQ). Adanya gangguan mental ditentukan jika menjawab minimal 6 gejala dari 20 gejala. ${ }^{15}$ Pengumpulan data konsumsi makanan dilakukan dengan cara recall 1×24 jam. Dalam memperkirakan porsi makanan/ minuman yang dikonsumsi responden, digunakan alat bantu dengan food models dan buku kode bahan makanan. Selanjutnya kandungan zat gizi dihitung dengan menggunakan program nutrisoft yang dikembangkan oleh Pusat Teknologi Terapan Kesehatan dan Epidemiologi Klinik, Balitbangkes. Pengelompokan kandungan zat gizi (energi dan protein) berdasarkan angka kecukupan gizi (AKG). Konsumsi zat gizi energi dikategorikan menjadi dua, yaitu defisit energi $(<70 \% \mathrm{AKG})$ dan cukup energi $(\geq 70 \%$ AKG). Konsumsi zat gizi protein dikategorikan menjadi dua, yaitu defisit protein $(<80 \% \mathrm{AKG})$ dan cukup protein $(\geq 80 \%$ AKG). Untuk konsumsi gula, natrium dan lemak mengacu pada Permenkes Nomor 30 Tahun 2013 tentang Pencantuman Informasi Kandungan Gula, Garam, dan Lemak serta pesan kesehatan untuk pangan olahan dan pangan siap saji. ${ }^{16}$ Konsumsi gula dikategorikan menjadi dua, yaitu $>50 \mathrm{~g}$ /hari dan $\leq 50 \mathrm{~g} /$ hari, konsumsi natrium yaitu $>2000 \mathrm{mg} /$ hari dan $\leq 2000 \mathrm{mg} /$ hari, sedangkan konsumsi lemak menjadi, $>60 \mathrm{~g} / \mathrm{hari}$ dan $\leq 60 \mathrm{~g} / \mathrm{hari}$.

Analisis data menggunakan program SPSS16 (serial number 5061284) dengan melakukan analisis bivariat untuk mengetahui adanya perbedaan proporsi antara KSM dengan variabel kovariat. Sedangkan pemodelan menggunakan uji logistik regresi untuk menentukan faktor risiko yang berperan terjadinya KSM dengan pengontrolan variabel lain.

Pertimbangan etik pelaksanaan penelitian telah memperoleh persetujuan dari Komisi Etik Penelitian Kesehatan (KEPK), Badan Penelitian dan Pengembangan Kesehatan Kementerian Kesehatan RI dengan nomor: LB.02.015/5.2/ KE.143/2014, tertanggal 17 April 2014. ${ }^{17}$ Izin Persetujuan Setelah Penjelasan (PSP) dimintakan dari seluruh calon responden secara tertulis dan ditandatangani sebelum dilakukan wawancara, pengukuran atau pemeriksaan.

\section{HASIL}

Setelah mengikuti pengamatan yang 
dilakukan 2 tahun, yaitu pada tahun 2014-2015 sebagai data dasar dan pengamatan pada tahun 2016-2017. Analisis dilakukan pada responden bebas dari KSM pada data dasar tahun 20142015, sebanyak 3041 orang, dengan rerata umur $47,6 \pm 9,7$ tahun.

Insidens rate $\mathrm{KSM}$ dalam kurun waktu 2 tahun sebanyak $21,6 \%$, hal ini menunjukkan sebanyak 216 orang per 1000 penduduk per dua tahun terjadi KSM di lima kelurahan di Kota Bogor Tengah. Proporsi insidens KSM lebih banyak pada kelompok umur 60 tahun atau lebih dibandingkan kelompok umur 25-59 tahun, jenis kelamin perempuan, pendidikan rendah, dan dengan status cerai. Tidak tampak perbedaan bermakna menurut pekerjaan dan status ekonomi berdasarkan upah minimal Kota Bogor tahun 2016 yaitu kurang dari Rp 3.022.765/ bulan (Tabel 1).

Analisis bivariat menunjukkan bahwa dari 19 kovariat, yang terdiri dari 13 kovariat perilaku dan faktor risiko, serta 6 kovariat komorditas. Hanya 8 kovariat yang menunjukkan hubungan bermakna terhadap KSM. Kovariat tersebut adalah indeks Brinkman, aktivitas fisik, obesitas sentral, asupan persentase lemak, asupan natrium, migrain, gangguan mental, dan stroke. (Tabel 2)
Analisis multivariat pada insiden KSM setelah pengamatan selama 2 tahun menunjukkan bahwa faktor risiko yang dapat diintervensi adalah aktivitas fisik, lingkar perut berisiko, dan asupan natrium.

Responden kurang melakukan aktivitas fisik, berisiko 1,9 kali (95\% CI:1,6-2,3) terhadap KSM dibandingkan responden dengan cukup aktivitas fisik. Responden dengan obesitas sentral, memiliki risiko 1,2 kali (95\% CI:1,01,5) terhadap KSM dibandingkan responden tidak obesitas sentral. Responden dengan asupan natrium $\geq 2000 \mathrm{mg}$ per hari, berisiko 0,6 kali (95\% CI:0,5-0,7) terhadap KSM dibandingkan responden dengan asupan natrium $<2000 \mathrm{mg}$ per hari, sementara responden dengan gangguan mental berisiko 1,9 kali (95\% CI:1,6-2,3) terhadap KSM dibandingkan responden tidak dengan gangguan mental. Responden dengan migrain berisiko 1,6 kali (95\% CI:1,3-1,9) terhadap KSM dibandingkan responden tidak migrain, dan responden kelompok umur $\geq 60$ tahun berisiko 1,9 kali (95\% CI:1,5-2,4) terhadap KSM dibandingan responden dengan kelompok umur 25-59 tahun. (Tabel 3)

Tabel 1. Proporsi Keluhan Subjektif Memori (KSM) menurut Karakteristik

\begin{tabular}{|c|c|c|c|c|c|c|c|c|}
\hline \multirow[t]{2}{*}{ Karakteristik } & \multicolumn{2}{|c|}{ Keluhan Subyektif Kognitif } & \multicolumn{2}{|c|}{$\begin{array}{c}\text { Tidak Ada Keluhan } \\
\text { Subyektif Kognitif }\end{array}$} & \multirow[t]{2}{*}{ Pvalue } & \multirow[t]{2}{*}{ OR } & \multicolumn{2}{|c|}{$95 \% \mathrm{CI}$} \\
\hline & $\mathbf{n}$ & $\%$ & n & $\%$ & & & Bawah & Atas \\
\hline \multicolumn{9}{|l|}{ Kelompok umur } \\
\hline $25-59$ th & 529 & 20,2 & 2085 & 79,8 &, 000 & 1,706 & 1,359 & 2.142 \\
\hline$>=60$ th & 129 & 30,2 & 298 & 69,8 & & & & \\
\hline \multicolumn{9}{|l|}{ Jenis kelamin } \\
\hline Laki & 126 & 14,9 & 720 & 85,1 & 0,000 & 0,547 & 0,442 & 0.677 \\
\hline Perempuan & 532 & 24,2 & 1663 & 75,8 & & & & \\
\hline \multicolumn{9}{|l|}{ Pendidikan } \\
\hline Rendah & 281 & 25,6 & 816 & 74,4 & 0,000 & 0,761 & 0,654 & 0,885 \\
\hline Sedang & 339 & 19,3 & 1416 & 80,7 & & & & \\
\hline Tinggi & 38 & 20,1 & 151 & 79,9 & & & & \\
\hline \multicolumn{9}{|l|}{ Pekerjaan } \\
\hline Tidak bekerja & 22 & 18,8 & 95 & 81,2 & 0,059 & 0,832 & 0,699 & 0,990 \\
\hline IRT/Pensiun & 349 & 23,4 & 1140 & 76,6 & & & & \\
\hline Kerja & 287 & 20,0 & 1148 & 80,0 & & & & \\
\hline \multicolumn{9}{|l|}{ Status perkawinan } \\
\hline Belum kawin & 21 & 13,6 & 133 & 86,4 & 0,000 & 1,594 & 1,271 & 1,999 \\
\hline Kawin & 554 & 21,3 & 2052 & 78,7 & & & & \\
\hline Cerai & 83 & 29,5 & 198 & 70,5 & & & & \\
\hline \multicolumn{9}{|l|}{ Status Ekonomi } \\
\hline$<$ UMR & 632 & 21,6 & 2291 & 78,4 & 0,915 & 1,024 & 0,657 & 1.597 \\
\hline$\geq \mathrm{UMR}$ & 26 & 22,0 & 92 & 78,0 & & & & \\
\hline Total & 658 & 21,6 & 2383 & 78,4 & & & & \\
\hline
\end{tabular}


Tabel 2. Proporsi Keluhan Subjektif KompleksMenurut Faktor Risiko dan Komorbiditas PTM

\begin{tabular}{|c|c|c|c|c|c|c|c|c|}
\hline \multirow{2}{*}{ Faktor Risiko } & \multicolumn{2}{|c|}{ Keluhan Subyektif Kognitif } & \multicolumn{2}{|c|}{$\begin{array}{c}\text { Tidak Ada Keluhan } \\
\text { Subyektif Kognitif }\end{array}$} & \multirow[t]{2}{*}{ Pvalue } & \multirow[t]{2}{*}{ OR } & \multicolumn{2}{|c|}{$95 \%$ CI } \\
\hline & $\mathbf{n}$ & $\%$ & $\mathbf{n}$ & $\%$ & & & Bawah & Atas \\
\hline \multicolumn{9}{|l|}{ Indeks Brinkman (IB) } \\
\hline Bukan perokok & 468 & 23,1 & 1560 & 76,9 & 0,014 & & & \\
\hline IB 1-599 batang & 159 & 18,2 & 714 & 81,8 & & & & \\
\hline $\mathrm{IB} \geq 600$ batang & 31 & 22,1 & 109 & 77,9 & & & & \\
\hline \multicolumn{9}{|l|}{ Aktivitas fisik } \\
\hline Cukup & 434 & 26,3 & 1219 & 73,7 & 0,000 & 1,850 & 1,545 & 2,215 \\
\hline Kurang & 224 & 16,1 & 1164 & 83,9 & & & & \\
\hline \multicolumn{9}{|l|}{ IMT } \\
\hline$<25 \mathrm{~kg} / \mathrm{m} 2$ & 260 & 20,9 & 983 & 79,1 & 0,422 & 1,075 & 0,901 & 1,282 \\
\hline$\geq 25 \mathrm{~kg} / \mathrm{m} 2$ & 398 & 22,1 & 1400 & 77,9 & & & & \\
\hline \multicolumn{9}{|l|}{ Obese sentral } \\
\hline Tidak & 200 & 18,8 & 866 & 81,2 & 0,005 & 1,307 & 1,085 & 1,574 \\
\hline Ya & 458 & 23,2 & 1517 & 76,8 & & & & \\
\hline \multicolumn{9}{|l|}{$\%$ Karbo } \\
\hline$<60 \% \mathrm{AKG}$ & 164 & 21,8 & 588 & 78,2 & 0,896 & 0,987 & 0,808 & 1,205 \\
\hline$\geq 60 \% \mathrm{AKG}$ & 494 & 21,6 & 1795 & 78,4 & & & & \\
\hline \multicolumn{9}{|l|}{$\%$ Protein } \\
\hline$<15 \%$ AKG & 288 & 21,3 & 1061 & 78,7 & 0,730 & 1,031 & 0,866 & 1,227 \\
\hline$\geq 15 \%$ AKG & 370 & 21,9 & 1322 & 78,1 & & & & \\
\hline \multicolumn{9}{|l|}{ \% Lemak } \\
\hline$<25 \%$ AKG & 32 & 29,9 & 75 & 70,1 & 0,034 & ,636 & 0,416 & ,971 \\
\hline$\geq 25 \%$ AKG & 626 & 21,3 & 2308 & 78,7 & & & & \\
\hline \multicolumn{9}{|l|}{ Natrium } \\
\hline$<2000 \mathrm{mg}$ & 461 & 25,6 & 1342 & 74,4 & 0,000 & 0,551 & 0,458 & 0,663 \\
\hline$\geq 2000 \mathrm{mg}$ & 197 & 15,9 & 1041 & 84,1 & & & & \\
\hline \multicolumn{9}{|l|}{ Gula } \\
\hline$<20 \mathrm{gr}$ & 385 & 21,7 & 1390 & 78,3 & 0,934 & 0,993 & 0,833 & 1,183 \\
\hline$\geq 20 \mathrm{gr}$ & 273 & 21,6 & 993 & 78,4 & & & & \\
\hline \multicolumn{9}{|l|}{ GDP } \\
\hline$\leq 99 \mathrm{gr} \%$ & 547 & 21,9 & 1951 & 78,1 & 0,455 & 0,916 & 0,729 & 1,152 \\
\hline$\geq 100 \mathrm{gr} \%$ & 111 & 20,4 & 432 & 79,6 & & & & \\
\hline \multicolumn{9}{|l|}{ GD } \\
\hline $\mathrm{pp}<140 \mathrm{gr} \%$ & 404 & 21,2 & 1505 & 78,8 & 0,409 & 1,078 & 0,902 & 1,287 \\
\hline$\geq 140 \mathrm{gr} \%$ & 254 & 22,4 & 878 & 77,6 & & & & \\
\hline \multicolumn{9}{|l|}{ T_Kolest } \\
\hline$\leq 199 \mathrm{mg} \%$ & 225 & 22,1 & 795 & 77,9 & 0,689 & 0,963 & 0,803 & 1,156 \\
\hline$\geq 200 \mathrm{mg} \%$ & 433 & 21,4 & 1588 & 78,6 & & & & \\
\hline \multicolumn{9}{|l|}{ LDL } \\
\hline$\leq 149 \mathrm{mg} \%$ & 63 & 23,9 & 201 & 76,1 & 0,358 & 0,870 & 0,646 & 1,171 \\
\hline$\geq 150 \mathrm{mg} \%$ & 595 & 21,4 & 2182 & 78,6 & & & & \\
\hline \multicolumn{9}{|l|}{ Hipertensi } \\
\hline Tidak & 461 & 21,6 & 1674 & 78,4 & 0,926 & 1,009 & 0,836 & 1,218 \\
\hline
\end{tabular}




\begin{tabular}{|c|c|c|c|c|c|c|c|c|}
\hline Ya & 197 & 21,7 & 709 & 78,3 & & & & \\
\hline \multicolumn{9}{|l|}{ Migrain } \\
\hline Tidak & 499 & 19,8 & 2021 & 80,2 & 0,000 & 1,779 & 1,441 & 2,196 \\
\hline Ya & 159 & 30,5 & 362 & 69,5 & & & & \\
\hline \multicolumn{9}{|c|}{ Gangguan mental } \\
\hline Tidak & 346 & 17,5 & 1630 & 82,5 & 0,000 & 1,952 & 1,637 & 2,327 \\
\hline Ya & 312 & 29,3 & 753 & 70,7 & & & & \\
\hline \multicolumn{9}{|l|}{ PJK } \\
\hline Tidak & 540 & 22,0 & 1914 & 78,0 & 0,315 & 0,892 & 0,713 & 1,115 \\
\hline Ya & 118 & 20,1 & 469 & 79,9 & & & & \\
\hline \multicolumn{9}{|l|}{ Stroke } \\
\hline Tidak & 633 & 21,4 & 2329 & 78,6 & 0,029 & 1,703 & 1,052 & 2,759 \\
\hline Ya & 25 & 31,6 & 54 & 68,4 & & & & \\
\hline \multicolumn{9}{|l|}{$\mathrm{DM}$} \\
\hline Tidak & 515 & 21,4 & 1897 & 78,6 & 0,453 & 1,084 & 0,878 & 1,338 \\
\hline Ya & 143 & 22,7 & 486 & 77,3 & & & & \\
\hline Total & 658 & 21,6 & 2383 & 78,4 & & & & \\
\hline
\end{tabular}

Tabel 3. Prediktor Insidens KSM dalam 2 Tahun Terakhir Studi Kohor FaktorRisiko PTM Bogor, Tahun 2016/2017

\begin{tabular}{|c|c|c|c|c|c|c|}
\hline & \multirow[b]{2}{*}{ B } & \multirow[b]{2}{*}{ SE } & \multirow[b]{2}{*}{ P value } & \multirow[b]{2}{*}{ OR } & \multicolumn{2}{|c|}{$95 \%$ CI for EXP (B) } \\
\hline & & & & & Lower & Upper \\
\hline Kelompok Umur & 0,624 & 0,122 & 0,000 & 1,865 & 1,467 & 2,372 \\
\hline Obesitas Sentral & 0,209 & 0,098 & 0,033 & 1,232 & 1,017 & 1,493 \\
\hline Asupan Natrium & $-0,558$ & 0,097 & 0,000 & 0,573 & 0,473 & 0,693 \\
\hline Aktivitas Fisik & 0,662 & 0,096 & 0,000 & 1,939 & 1,607 & 2,339 \\
\hline Migrain & 0,446 & 0,113 & 0,000 & 1,562 & 1,252 & 1,948 \\
\hline Gangguan Mental & 0,628 & 0,093 & 0,000 & 1,874 & 1,561 & 2,251 \\
\hline Constant & $-2,044$ & 0,118 & 0,000 & 0,130 & & \\
\hline
\end{tabular}

\section{PEMBAHASAN}

Saat ini, ada pengakuan dan pemahaman yang meningkat tentang KSM, sebagai manifestasi klinis pertama penyakit Alzheimer atau kondisi terkait lainnya, seperti demensia vaskular. Penelitian membuktikan bahwa kelompok ini memiliki prevalensi biomarker positif untuk amiloidosis dan neurode generasi yang lebih tinggi. Penegakan diagnosis dini dalam manajemen pencegahan dengan mengoptimalkan kesehatan fisik, kognitif, aktivitas, pengobatan, perbaikan perilaku, dan psikologis merupakan dukungan jangka panjang untuk meningkatkan kesejahteraan masyarakat. ${ }^{18}$

Hasil penelitian studi kohor faktor risiko PTM di Kota Bogor menunjukkan insidens KSM sebesar 216 orang per 1.000 penduduk per 2 tahun pada responden dengan rata-rata umur 47,6 $\pm 9,7$ tahun. Sebanyak 30,2\% responden dengan umur $\geq 60$ tahun mengalami KSM. Meskipun umur merupakan faktor risiko yang paling kuat untuk terjadinya demensia, tetapi demensia bukan merupakan konsekuensi penuaan yang tidak dapat dihindarkan. Dalam analisis, KSM tidak sematamata terjadi pada kelompok umur lanjut. Hal tersebut juga ditemukan 20,2\% pada kelompok umur 25-59 tahun, seperti yang dikemukakan WHO, gejala demensia dapat terjadi sebelum umur 60 tahun, dan kejadian demensia muda menyumbangkan sampai $9 \%$ dari kasus. ${ }^{4}$

Beberapa penelitian menunjukkan hubungan antara perkembangan gangguan 
kognitif, faktor risiko terkait gaya hidup dan penyakit tidak menular. Disamping pengaruh lingkungan sebagai latar belakang genetik memainkan peran dalam terjadinya KSM. ${ }^{19}$ Faktor risiko terkait gaya hidup termasuk aktivitas fisik, obesitas, diet tidak sehat, penggunaan tembakau, penggunaan alkohol yang berbahaya, diabetes, dan hipertensi. Dalam analisis bivariat didapatkan faktor risiko yang mempunyai hubungan dengan insiden KSM adalah indeks Brinkman, aktivitas fisik, obesitas senteral, asupan persen lemak dalam makanan, asupan natrium, migren, stroke, dan gangguan mental. Sedangkan faktor sosio demografi yang mempunyai hubungan dengan insiden KSM adalah kelompok umur, jenis kelamin, pendidikan, dan status perkawinan,

Analisis multivariat setelah dikontrol dengan variabel umur dan telah dilakukan uji interaksi, model akhir prediktor yang berpengaruh terhadap KSM adalah aktivitas fisik, gangguan mental, migrain, obesitas sentral, dan asupan natrium.

Penelitian Keskinoglu, ${ }^{20}$ pada 490 orang lansia dengan umur rata-rata 71,8 tahun, didapatkan prevalensi demensia sebanyak 12,9\%. Diantaranya $34,7 \%$ dari lansia tersebut buta huruf dan $12 \%$ tinggal sendirian. Tingginya prevalensi demensia kemungkinan karena efek kumulatif dari beberapa faktor risiko yang tidak menguntungkan seperti kondisi sosial ekonomi yang buruk, adanya penyakit serebrovaskular dan rendahnya tingkat pendidikan. Sedangkan penelitian pada penduduk Benin (Afrika Barat) berumur 65 tahun keatas, dengan menggunakan wawancara dan tes lima kata, didapatkan prevalensi demensia sebanyak 3,7\% (95\% CI: 2,6$4,8)$. Angka itu meningkat seiring bertambahnya umur, dan lebih tinggi di kalangan perempuan daripada laki-laki. ${ }^{21}$

Responden kurang melakukan aktivitas fisik, berisiko 1,9 kali (95\% CI:1,6-2,3) terhadap insidens KSM dibandingkan responden cukup aktivitas fisik. Hal ini diperkuat dengan beberapa hasil penelitian yang menilai efek latihan fisik pada kognitif. Penelitian menyimpulkan bahwa latihan fisik merupakan kandidat pengobatan nonfarmakologis bagi responden demensia untuk dapat melakukan kegiatan sehari-hari. ${ }^{22}$ Demikian juga survei yang menyelidiki kognisi, aktivitas fisik, dan perilaku menetap (membaca, nonton $\mathrm{TV}$, dll) menyimpulkan bahwa peningkatan aktivitas fisik dan waktu membaca kemungkinan berhubungan dengan penurunan risiko KSM di komunitas. ${ }^{23}$ Berdasarkan hasil-hasil penelitian di atas, penulis menyimpulkan bahwa ada bukti efektif aktivitas fisik dalam meningkatkan kognisi dan hasil lainnya pada orang dengan demensia. ${ }^{22}$

Responden dengan migrain berisiko 1,6 kali (95\% CI:1,3-1,9) terhadap KSM dibandingkan responden tidak migrain. Pada perempuan lebih banyak dibandingkan laki-laki. Temuan ini hampir sama dengan hasil studi kohor migrain di Taiwan. Responden migrain memiliki risiko 1,33 kali lipat lebih tinggi terkena demensia [rasio hazard (HR) 1,33, 95\% confidence interval (CI) 1,22-1,46]. Analisis Kaplan-Meier menunjukkan bahwa insidens kumulatif demensia adalah 1,48\% lebih besar pada kelompok migrain dibandingkan pada kelompok non-migrain (uji log-rank, $p<0,0001)$. Hubungan antara migrain dan demensia lebih banyak terjadi pada dewasa muda dibandingkan dengan kelompok umur yang lebih tua. ${ }^{24}$ Demikian juga penelitian pada 188 responden dengan migrain, rerata umur 38,1 $\pm 9,9$ tahun, hasil menunjukkan bahwa migrain, depresi, dan gangguan durasi tidur berhubungan dengan KSM pada migrain dewasa. ${ }^{25}$ Sementara penelitian Lee mendapatkan bahwa, responden pada kelompok umur kurang dari 45 tahun, migrain lebih berisiko pada stroke dibandingkan dengan responden yang lebih tua, dan asosiasi terkuat antara migrain dan stroke terjadi pada responden tanpa faktor risiko stroke pada umumnya seperti tekanan darah tinggi, diabetes melitus dan kolesterol tinggi. ${ }^{26}$

Responden dengan gangguan mental berisiko dengan OR 1,9 kali (95\% CI:1,62,3) terhadap KSM dibandingan responden tidak dengan gangguan mental. Temuan ini hampir serupa dengan penelitian di Korea yang menggunakan CERAD-K Neuropsychological Assessment Battery untuk mendiagnosis KSM. Hasil analisis mendapatkan prevalensi demensia umum sebesar 8,1\% (95\% CI: 6,9-9,2) dan KSM sebesar 24,1\% (95\% CI: 21,0-27,2). Peningkatan risiko demensia terjadi pada kelompok umur yang 
lebih tua, pada laki-laki, tingkat pendidikan lebih rendah atau buta huruf, merokok, dan mempunyai riwayat trauma kepala atau gangguan mental atau depresi. Diperkirakan jumlah demensia akan meningkat dua kali lipat setiap 20 tahun, sehingga pada tahun 2050 penyakit Alzheimer akan meningkat di Korea. Hal ini sekaligus menjelaskan kasus demensia yang semakin meningkat di masa depan. ${ }^{27}$ Kondisi serupa juga akan terjadi di Indonesia.

Responden dengan asupan natrium $\geq 2000 \mathrm{mg}$ per hari, berisiko $0,6 \mathrm{kali}$ (95\% CI: 0,5-0,7) terhadap KSM dibandingkan responden dengan asupan natrium $<2000 \mathrm{mg}$ per hari. Hal ini sesuai dengan hasil studi longitudinal pada laki-laki kulit putih $(\mathrm{n}=373)$ dan perempuan ( = 552), berumur 50-96 tahun dari Studi Rancho Bernardo. Asupan natrium yang lebih rendah dikaitkan dengan fungsi kognitif yang buruk pada orang dewasa. ${ }^{28}$

Responden dengan obesitas sentral, memiliki risiko 1,2 kali $(95 \%$ CI:1,0-1,5) terhadap KSM dibandingkan responden tidak obesitas sentral. Temuan ini sejalan dengan hasil dari penelitian Kerwin pada 7.163 perempuan kelompok umur 65-80 tahun yang tidak demensia, bahwa sentral obesitas sebagai faktor risiko gangguan kognitif dan kemungkinan akan menjadi demensia sekalipun dengan indeks massa tubuh normal. ${ }^{29}$

Keterbatasan dalam penelitian ini, analisis KSM baru dapat dinilai dalam satu kali pengamatan yaitu 2 tahun setelah pengumpulan data dasar pada tahun 2014-2015.

\section{KESIMPULAN}

Insidens rate KSM sebanyak 216 orang per 1000 penduduk setiap tahunnya dalam pemantauan 2 tahun (2014/2015 - 2016/2017) di lima kelurahan di Kota Bogor Tengah, daerah studi kohor faktor risiko penyakit tidak menular. Model akhir insidens KSM setelah menyesuaikan faktor umur, adalah kurang aktivitas fisik (OR 1,9 kali, 95\% CI:1,6-2,3), obesitas sentral (OR 1,2 kali, 95\% CI:1,0-1,5), asupan natrium $\geq 2000 \mathrm{mg}$ per hari (OR 0,6 kali, 95\% CI: 0,5-0,7), gangguan mental (OR 1,9 kali, 95\% CI:1,6-2,3) dan migrain (OR 1,6 kali, 95\% CI:1,3-1,9) terhadap insidens KSM.

\section{SARAN}

Intervensi spesifik perlu dilakukan pada perilaku berisiko penyebab KSM, dengan lebih meningkatkan aktivitas fisik secara rutin, pertahankan berat badan ideal dengan lingkar perut tidak berisiko, hindari stres dan kontrol asupan garam terutama pada responden lanjut usia dengan asupan tidak terlalu rendah.

\section{UCAPAN TERIMA KASIH}

Penulis mengucapkan terima kasih kepada Departemen Neurologi Rumah Sakit Umum Pusat Dr.Cipto Mangunkusum kerjasamanya dalam tim studi kohor faktor risiko Penyakit Tidak Menular. Juga pada Prof. dr.Yuda Turana, SpS atas kerjasamanya dalam tim Studi Kohor Faktor Risiko Penyakit Tidak Menular dan bimbingan dalam menyelesaikan tulisan ini. Tidak lupa pada tim kohor yang telah mendukung dalam penulisan artikel ini.

\section{DAFTAR PUSTAKA}

1. Postuma RB, Berg D, Stern M, et.al. MDS clinical diagnostic criteria for Parkinson's disease. Mov Disord. 2015 Oct;30(12):1591601.doi: 10.1002/mds.26424.

2. Sieber BA, Landis S, Koroshetz W, et.al. Parkinson's Disease 2014: Advancing Research, Improving Lives Conference Organizing Committee. Ann Neurol, 2014 Oct;76(4):469-72, doi: 10.1002/ana.24261. Epub 2014 Sep 23.

3. Gauthier S1, Reisberg B, Zaudig M, et.al; Mild cognitive impairment.Lancet. 2006 Apr 15;367(9518):1262-70.

4. World Health Organization. Dementia Fact sheet WHO Updated December 2017.

5. Badan Pusat Statistik. Statistik penduduk lanjut usia 2015. Jakarta: Badan Pusat Statistik Jakarta. 2016.

6. Undang-Undang Nomor 13 Tahun 1998 tentang Kesejahteraan Lanjut Usia pada Bab1 Pasal 1 Ayat 2.

7. World Health Organization,Global Physical Activity Questionnaire (GPAQ). Geneva: WHO; 2011.http://www.who.int/chp/steps/ GPAQ/en/inde x.html.

8. World Health Organization. Global recommendations on physical activity for 
health. Geneva: WHO; 2010.

9. Kementerian Kesehatan.Pedoman Pengukuran dan Pemeriksaan. Jakarta : Badan Litbang Kesehatan. 2013.

10. World Health Organization. Waist circumference and waist-hip ratio: report of a WHO expert consultation. Geneva, Switzerland: World Health Organization; 2008.

11. National Cholesterol Education Program (NCEP) Expert Panel on Detection, Evaluation, and Treatment of High Blood Cholesterol in Adults (Adult Treatment Panel III). Circulation, 2002 Dec 17; 106(25):3143421.[PubMed] [Ref list]

12. James PA, Oparil S, Carter BL, et al. Evidencebased guideline for the management of high blood pressure in adults: Report from the panel members appointed to the Eighth Joint National Committee (JNC 8). JAMA 2014;311:507-20.

13. World Health Organization expert consultation, Appropriate body-mass index for Asian populations and its implications for policy and intervention strategies. Lancet 2004;363:157-63.

14. American Diabetes Association. Classification and diagnosis of diabetes. Diabetes Care 2015;38(Suppl 1):S8-S16

15. Stratton KJ, Aggen SH, Richardson LK, Acierno R, Kilpatrick DG, Gaboury MT, et al. Evaluation of the psychometric properties of the Self-Reporting Questionnaire (SRQ20) in a sample of Vietnamese adults. Compr Psychiatry, 2013;54(4):398-405.

16. Peraturan Menteri Kesehatan Nomor 30 Tahun 2013 tentang Pencantuman Informasi Kandungan Gula, Garam, dan Lemak Serta Pesan Kesehatan Untuk Pangan Olahan dan Pangan Siap Saji (Berita Negara Republik Indonesia Tahun 2013 Nomor 617.

17. Surat Persetujuan Komisi Etik Balitbangkes tahun 2014

18. Adalberto Studart Neto, Ricardo Nitrini. Subjective cognitive decline:The first clinical manifestation of Alzheimer's disease? Dement Neuropsychol 2016 September;10(3):170-177.
19. Barbara Caracciolo, PhD, Margaret Gatz, $\mathrm{PhD}$, Weili Xu, MD PhD,et.al. Differential distribution of subjective and objective cognitive impairment in the population: A nationwide twin-study. $\mathrm{J}$ Alzheimers Dis. 2012; 29(2): 393-403.doi: 10.3233/ JAD-2011-111904. PMCID: PMC4063353. NIHMSID: NIHMS591812PMID: 22233768

20. Keskinoglu P, Yaka E, Ucku R, et.al. Prevalence and risk factors of dementia among community dwelling elderly people in Izmir, Turkey.Turk GeriatriDergisi. 2013;16(2):13541. PubMed PMID: 2013370970. Izmir' deyasayanyaslilardademanssikligive risketmenleri

21. Paraiso MN, Guerchet M, Saizonou J.et. al.Prevalence of dementia among elderly people living in Cotonou, an urban area of Benin (West Africa), Neuroepidemiology, 2011 2011;36(4):245-51. PubMed PMID: 2011579187.

22. Forbes D1, Forbes SC, Blake CM, Thiessen EJ, Forbes S, Exercise programs for people with dementia. Cochrane Database Syst Rev. 2015 Apr 15;(4):CD006489.doi: 10.1002/14651858.CD006489.pub4.

23. Nemoto Y, Sato S, Takahashi M, et al. (2018) The association of single and combined factors of sedentary behavior and physical activity with subjective cognitive complaints among community-dwelling older adults: Cross-sectionalstudy.PLoS ONE 13(4): e0195384. https://doi.org/

24. Chuang CS1, Lin CL, Lin MC, Sung FC, Kao $\mathrm{CH}$. Migraine and risk of dementia: a nationwide retrospective cohort study. Neuroepidemiology. 2013;41(3-4):139-45. doi: 10.1159/000353559. Epub 2013 Jul 30.

25. Sun Hwa Lee, Yeonwook Kang and Soo-Jin Cho.Subjective cognitive decline in patients with migraine and its relationship with depression, anxiety, and sleep quality. The Journal of Headache and Pain (2017) 18:77. DOI 10.1186/s10194-017-0779-1.

26. Lee MJ, Lee C, Chung CS.The migrainestroke connection. J Stroke 2016; 18:146-56.

27. Kim KW, Park JH, Kim M-H, Kim MD, Kim B-J, Kim S-K, et al.A nationwide survey on 
the prevalence of dementia and mild cognitive impairment in South Korea. Journal of Alzheimer's Disease. 2011 2011;23(2):28191.doi: 10.3233/JAD-2010-101221.

28. Toni M Rush, Donna Kritz-Silverstein, Gail A Laughlin, et.al.Association between Dietary Sodium Intake and Cognitive Function in Older Adults. J Nutr Health Aging, 2017; 21(3): 276-283.doi: 10.1007/s12603-016-
0766-2. PMCID: PMC5334786. NIHMSID: NIHMS810447. PMID: 28244567

29. Kerwin DR1, Gaussoin SA, Chlebowski RT, et.al.Interaction between body mass index and central adiposity and risk of incident cognitive impairment and dementia: results from the Women's Health Initiative Memory Study. J Am Geriatr Soc. 2011 Jan;59(1):10712.doi: 10.1111/j.1532-5415.2010.03219.x. 